\title{
Analysis of the Influence of Regional Leading Sectors on Economic Growth in West Aceh District, Aceh Province
}

\author{
Yayuk Eko Wahyuningsih \\ \{yayukew@utu.ac.id\} \\ Lecturer in Faculty of Economic University of Teuku Umar Kampus Alpen Street West Aceh \\ District, Indonesia
}

\begin{abstract}
West Aceh district is one of the old towns in the South West Region. This district is identified as the region which has various leading economic potentials especially in agricultural sector that can increase it's economic growth. This study aims to analyze the influence of regional leading sectors on economic growth in this district. Furthermore, the data used in this study is secondary data (1997-2016) which is retrieved by Central Bureau of Statistics Aceh Province (BPS) and Regional Development Planning Agency (Bappeda) of West Aceh District. The method used is quantitative method applying Location Quotient (LQ) analysis and simple linear regression. Based on the result of the research, it was obtained that the correlation coefficient value is 0.642 and the coefficient of determination value is $41.2 \%$. Moreover, regression equation value is $\mathrm{Y}=7.953-1.064 \mathrm{X}_{1+\mathrm{e}}$. Therefore, it is suggested that local government increases the previous leading sectors and further diverts the potential of non-leading sectors become potential leading sectors thus regional economic growth is increasing.
\end{abstract}

Keywords: $\quad$ leading sectors, non-leading sectors and economic growth

\section{Introduction}

The World Bank estimates global economic growth will increase by 31 percent in 2018 after economic growth in 2017 is much stronger than expected due to the continuing recovery in investment, manufacturing and trade as well as developing countries that export commodities benefit from stronger commodity prices (https://www.worldbank.org, no date)

Based on the statement above it can be inferred that economic growth is not always increasing, but is always fluctuating which is influenced by other factors within a country. The Indonesian economy in 2017 grew 5.07 percent higher than that of 2016 achievement that is 5.03 percent. In terms of production, the highest growth was achieved by the company's services business sector by 9.25 percent. In terms of expenditure, the highest growth was achieved by the component of goods and services exports by 8.50 percent (https://www.bps.go.id, 2018).

Furthermore, the Aceh economy in the fourth quarter of 2017 with oil and gas grew by 4.19 percent and without oil and gas 4.14 percent (https://aceh.bps.go.id, 2018).This number is still far below national rank. Likewise in West Aceh Regency which is part of the western tip of Sumatra province. According to BPS (2017) ${ }^{[4]}$ that one of the superior economic sectors today in West Aceh Regency is the agriculture and 
trade sector. For agriculture includes rice paddy and oil palm plantations. Whereas for superior sector trade are grocery stores, coffee shops and food / beverage businesses.

\section{Literature Review}

\subsection{Regional Leading Sector}

According to (Tarigan, 2013) economic activities are grouped based on basic and non-basic activities. Only basic activities can drive regional economic growth. Furthermore (Tarigan, 2013) says all other activities that are not basic activities are included in the service / service sector or service, but not to create a false understanding of the meaning of service or can be called as non-base sector.

\subsection{Gross Regional Domestic Product (GRDP)}

Regional GDP can be used to measure the superiority of a sector compared to the Gross National Product (GNP) nationally. In general, GRDP consists of 9 sectors, namely: agriculture sertor, mining / excavation, processing industry, electricity and drinking water, buildings, trade, hotels and restaurants, transportation, finance / insurance and services, although in recent years it has become 17 sectors.

\subsection{Economic Growth}

According to (Todaro and Smith, 2015) economic growth is a process of increasing productive capacity in an economy continuously and national output which is getting bigger and bigger. Furthermore, according to (Jhingan, 2007, p. 57) economic growth is as an increase in long-term output in the ability of a country to provide more and more types of economic goods to its population, this ability grows in accordance with technological progress and institutional and ideological adjustments needed.

\subsection{Regional Economic Development}

Regional economic development is process oriented. A process that involves the formation of new institutions, development of alternative industries, improvement of existing workforce capacity to produce better products, identification of new markets (Adisasmita, 2005, p. 19). Based on the above explanation it is clear that regional economic development is needed in managing existing natural resources, between local governments and communities to create new jobs and so that the GRDP and PNB values increase in the area.

\subsection{Hypothesis Formulation}

The hypothesis of this study is that it is suspected that the leading sector has a significant and positive effect on economic growth in West Aceh District.

\section{Methodology}

\subsection{Scope of Research}

Including the PNB of Aceh Province and the GRDP of West Aceh District and the economic growth of West Aceh District for 20 years in the period 1997-2016. 


\subsection{Data Analysis Models}

The data analysis model used is quantitative analysis using quasi-location analysis and simple linear regression.

\subsection{Location Quotation Analysis}

According to (Tarigan, 2009, p. 82) Location Quotient (quasien location) or abbreviated as LQ is a comparison of the magnitude of the role of a sector / industry in an area towards the magnitude of the role of a sector / industry nationally. The formula is as follows.

$\mathrm{LQ}=\frac{\frac{x 1}{P D R B}}{P N B}$

Where:

xi : Value added of sector $\mathrm{i}$ in West Aceh District

GRDP : Gross Regional Domestic Product of West Aceh District

xi: $\quad$ : Value added of the Aceh Province of i sector

GDP: : Gross Domestic Product of Aceh Province

If $L Q>1$ : means that the role of the sector in the area is more prominent than the role of the sector nationally and vice versa.

\subsection{Simple Linear Regression Analysis}

According to (Syakhiruddin, 2008, p. 248) the calculation formula is as follows:

$\mathrm{yi}=\mathrm{a}+\mathrm{bxi}+\mathrm{e}$

Where

yi : Economic growth

a : Intercept (constant)

b : Factor xi regression coefficient

xi : LQ value of the leading sector per year

e : Error term

\subsection{Hypothesis Testing}

Based on testing this hypothesis, if:

- $\mathrm{H} 0 ; \beta 1=0$, it is assumed that the leading sector has no significant effect on economic growth in West Aceh District.

- $\mathrm{H} 1 ; \beta 1 \neq 0$, it is assumed that the leading sector has a significant effect on economic growth in West Aceh District.

The test criteria are carried out by t test

\section{Results And Discussion}

\subsection{Leading Sector of West Aceh District}

The results of the study showed that the superior sector value using location and ranked quota analysis based on the highest sector for 20 years can be seen in the following graph. 


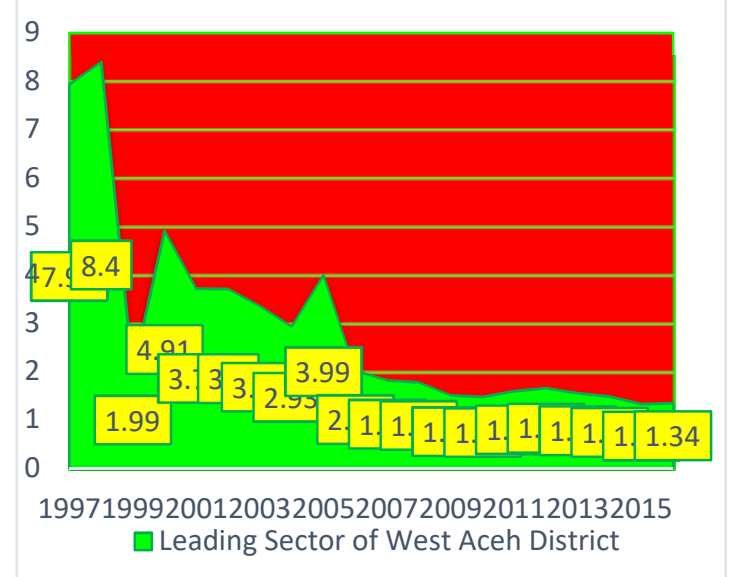

Fig. 1. LQ of the Leading Sector in West Aceh District in 1997-2016

Figure 1: describes that the highest leading sector in Aceh Barat District occurred in 1997 amounting to 7.93 at which the monetary crisis had not yet occurred in Indonesia which had an impact on the provinces / districts in it. Similarly, in 1998 it increased by 8.40 and decreased drastically in the following year (1999) by 1.99 as a result of the 1998 monetary crisis and continued to fluctuate in a decreasing manner as in the picture above.

\subsection{Economic Growth of West Aceh District}

The data on the economic growth of West Aceh District during 1997-2016 period can be seen in graph 2 below:

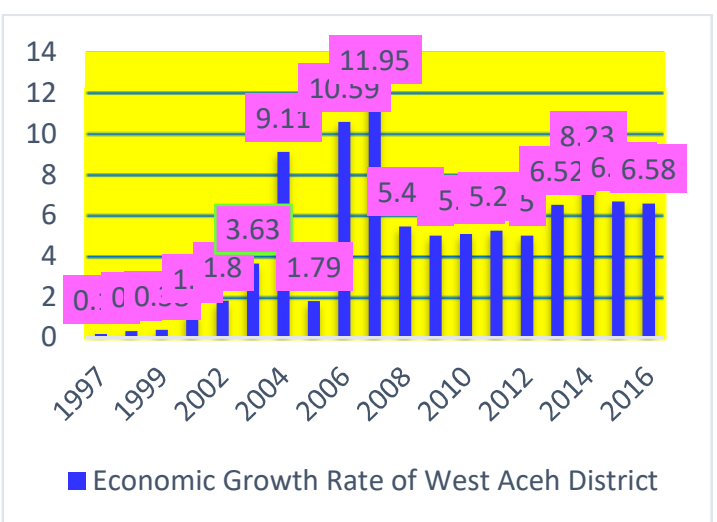

Fig. 2.Economic Growth Rate of West Aceh District in 1997-2016 Source: Central Bureau of Statistics Aceh Province (Research on June 2018)

Based on graph 2, it can be seen that economic growth occurred in 2007 amounting to 11.95 percent, due to the presence of humanitarian institutions both locally, nationally and internationally. In addition, there was a large scale of 
development in this year, especially physical facilities as a result of the earthquake and tsunami disaster in this district by building roads, bridges, houses, hospitals, schools, offices and so on. While the lowest economic growth occurred at the time of the monetary crisis in Indonesia at 1997, 1998 and 1999 with growth of 0.16 percent, 0.30 percent and 0.38 percent, respectively.

\subsection{Discussion}

\subsubsection{Location Quotation Analysis}

The leading sector data according to the business or sector field can be seen in the following table:

Table 1. Leading Sector in West Aceh District 1997-2016

\begin{tabular}{|c|c|c|c|}
\hline No & Year & Leading Sectors & The name of sectors/ / business field \\
\hline 1 & 1997 & 7,93 & Services \\
\hline 2 & 1998 & 8.40 & Services \\
\hline 3 & 1999 & 1,99 & Finance, leasing and financial services \\
\hline 4 & 2000 & 4,91 & Buildings \\
\hline 5 & 2001 & 3,71 & Services \\
\hline 6 & 2002 & 3,70 & Services \\
\hline 7 & 2003 & 3,35 & Buildings \\
\hline 8 & 2004 & 2,93 & Buildings \\
\hline 9 & 2005 & 3,99 & Buildings \\
\hline 10 & 2006 & 2,01 & Services \\
\hline 11 & 2007 & 1,82 & Trade, hotel and rstaurant \\
\hline 12 & 2008 & 1,77 & Services \\
\hline 13 & 2009 & 1,51 & Services \\
\hline 14 & 2010 & 1,47 & Services \\
\hline 15 & 2011 & 1,59 & Services \\
\hline 16 & 2012 & 1,65 & Services \\
\hline 17 & 2013 & 1,55 & Services \\
\hline 18 & 2014 & 1,48 & Services \\
\hline 19 & 2015 & 1,33 & Services \\
\hline 20 & 2016 & 1,34 & Services \\
\hline
\end{tabular}

Based on the table above, the business sectors in the leading sectors are generally centered on services, buildings after the earthquake and tsunami and the trade / hotel and restaurant sector due to the presence of humanitarian workers from outside of this district.

This is in line with the research of (Azhar, Fuaidah and Abdussamad, 2012) showing that the leading agricultural sector is also the basis, but not the main one.

\subsubsection{Simple Linear Regression Analysis}

Table 2. Simple Linear Regression

\begin{tabular}{lll}
\hline No & Variabel & Estimation coefficient \\
\hline 1 & Constant & 7,953 \\
\hline
\end{tabular}




\begin{tabular}{lll}
\hline 2 & Leading Sector coefficient & $-1,064$ \\
\hline 3 & Correlation coefficient & 0.642 \\
\hline 4 & Coefficient of determination & 0,412 \\
\hline
\end{tabular}

Based on Table 2, the regression equation is obtained as follows:

$\mathrm{Y}=7,953-1,064 \mathrm{X} 1+\mathrm{e}$

The linear regression equation can be interpreted as follows:

a. Constant

A constant value of 7.953 means that if the leading sector and economic growth are equal to zero, then the constant value is 7.953

b. The leading sector variable coefficient

Coefficient value of -1.064 means that if the leading sector rises by 1 then economic growth falls by 1.064 percent

c. Correlation coefficient

Based on the results of research conducted it can be explained that the correlation coefficient $(\mathrm{R})$ of 0.642 means that there is a moderate relationship between the leading sectors and economic growth in this district

d. Determination Coefficient Analysis

The value of the determination coefficient ( $\mathrm{R}$ adj) of 0.412 means that 41.2 percent of economic growth is influenced by the leading sector and the remaining 58.8 percent is contributed by other variables outside this research model.

e. t-Test

The leading sector $t-v a l u e ~ i s ~ 3.555$ significant at $\alpha=5 \%(0.002)$.

\section{Conclusions}

a. The leading sector has a negative and significant effect on economic growth in the West Aceh District in the period of 1997-2016.

b. The dominant sector that dominates includes services, buildings and trade / hotels and restaurants.

\section{Suggestions}

The Government of West Aceh District, should pay attention to the leading sector and maintain its existence. The Government of West Aceh District needs to develop other sectors even though the numbers are very small.

\section{Acknowledgements}

This conference was supported by Prof. Dr. Jasman, J. Ma'ruf, SE, MBA (Rector of Teuku Umar University), Dr .Ishak. M.Si (Dean of Economic Faculty), Head of Department of Economic Development, Head of Central Bureau of Statistics Aceh Province and others.

\section{REFERENCES}

[1] Adisasmita, R. (2005) Basic Basis of Ekonomic Regional. Yogyakarta: Graha Ilmu. 
[2] Azhar, S., Fuaidah, L. and Abdussamad, M. N. (2012) Leading Sectors and Non Leading Sectors Analysis in Nanggroe Aceh Darussalam Province. Aceh.

[3] https://aceh.bps.go.id (2018).

[4] https://www.bps.go.id (2018).

[5] https://www.worldbank.org (no date).

[6] Jhingan, M. (2007) Ekonomic Development and Planning. Jakarta: PT. Raja Grafindo Persada.

[7] Syakhiruddin, S. (2008) Statistic of Ekonomy. Aceh: Syiah Kuala University Press.

[8] Tarigan, R. (2009) Regional Economic: Theory and Applications. Jakarta: Bumi Aksara.

[9] Tarigan, R. E. (2013) 'Peranan Sistem Informasi dengan Online Trading Terhadap Pertumbuhan Pasar Modal di Indonesia Teori Investasi', (27), pp. 803-811.

[10] Todaro, M. P. and Smith, S. C. (2015) Economic Development. 12 th Edit. New York: The George Washington University. 